20 Управління фінансово-економічною безпекою [Текст]: навч. посібник / Кириченко О.А., Лаптєв С.М., Пригунов П.Я., Захаров О.I. та ін. - К.: Дорадо-Друк, 2010. - 480 с.

21 Павліченко В.М. Податкова безпека як складова економічної безпеки українських підприємств в умовах кризи / В.М. Павліченко // Вісник економіки транспорту і промисловості. - Вип. 49. - 2015. - С. 131-135

Рецензент д.е.н., професор УкрДУЗТ Компанієць В.В. Експерт редакційної колеаії к.е.н., доцент УкрДУЗТ Назаренко І.Л.

УДК: 658.11 (477)

\title{
ФОРМУВАННЯ КОНКУРЕНТНОЇ СТРАТЕГІЇ ПІДПРИМСТВ ЗАЛІЗНИЧНОГО ТРАНСПОРТУ УКРАЇНИ
}

\author{
Підопригора І.В., к.е.н., доцент (УкрДУЗТ)
}

В статті окреслені особливості функиіонування підприємств залізничного транспорту Украӥни в умовах реформування галузі, жорсткої ринкової економіки та глобалізації. Обтрунтована необхідність формування конкурентної стратегії для підприємств залізничного транспорту. Визначено поняття конкурентна стратегія підприємства та доведено, що від ї̈ правильного вибору залежать всі подальші виробничі, маркетингові, фінансові та інші дії підприємства. 3 метою забезпечення ефективності діяльності підприємств залізничного транспорту Украӥни виділено ключові аспекти формування конкурентної стратегії. Доведено, що вже після формування конкурентної стратегії слід вирішити три взаємопов'язані завдання: управління стратегією на ринку (розробка, реалізаиія та уточнення стратегій, що забезпечують перемогу на ринку); управління організацією; реалізачія стратегічного менеджменту (взаємодія між стратегією і організаційними процесами).

Ключові слова: стратегія, стратегічне управління, конкурентоспроможність, підприсмство, залізничний транспорт.

\section{ФОРМИРОВАНИЕ КОНКУРЕНТНОЙ СТРАТЕГИИ ПРЕДПРИЯТИЙ ЖЕЛЕЗНОДОРОЖНОГО ТРАНСПОРТА УКРАИНЫ}

\section{Подопригора И.В., к.э.н., доцент (УкрГУЖТ)}

В статье рассмотрены особенности функиионирования предприятий железнодорожного транспорта в условиях реформирования отрасли, жесткой рыночной экономики и глобализации. Обоснована необходимость формирования конкурентной стратегии для предприятий железнодорожного транспорта. Определено понятие конкурентная стратегия предприятия и доказано, что от ее правильного выбора зависят все дальнейшие производственные, маркетинговые, финансовые и другие действия предприятия. $C$ целью обеспечения эффективности деятельности предприятий железнодорожного транспорта Украины выделень ключевые аспекты формирования конкурентной стратегии. Доказано, что уже после формирования конкурентной стратегии необходимо решить три взаимосвязанные задачи: управление стратегией на рынке (разработка, реализация и уточнение стратегий, обеспечиваюших победу на рынке); управление организацией; реализация стратегического менеджмента (взаимодействие между стратегией и организачионными проиессами).

Ключевые слова: стратегия, стратегическое управление, конкурентоспособность, предприятие, железнодорожный транспорт.

(C) Підопригора I.B.

Вісник економіки транспорту і промисловості № 51, 2015 


\title{
FORMATION OF THE COMPETITIVE STRATEGY OF ENTERPRISES OF RAILWAY TRANSPORT OF UKRAINE
}

\author{
Podoprigora I. V., candidate of economics, associate professor (UkrURT)
}

In the article the peculiarities of functioning of the enterprises of railway transport in the conditions of reforming of the industry, rigid market economy and globalization. It justifies a necessity of formation of competitive strategies for railway companies. Define the concept of competitive strategy of the enterprise and proved that the correct choice depends on all further production, marketing, financial and other activities of the enterprise. With the aim of ensuring the efficiency of enterprises of railway transport of Ukraine highlighted the key aspects of the competitive strategy. It is proved that after the formation of the competitive strategy must accomplish three interrelated objectives: the management strategy (development, implementation and refinement of strategies to ensure victory on the market); organization management; strategic management (interaction between strategy and organizational processes).

Keywords: strategy, strategic management, competitiveness, enterprise, railway transportation.

Постановка проблеми. Постійні зміни макросередовища призвели до докорінних змін як зовнішніх, так і внутрішніх економічних умов господарювання вітчизняних підприємств. Це створило нову економічну систему господарювання, що змушує підприємства залізничного транспорту гнучко адаптуватися до нестабільного розвитку ринкової кон'юнктури. Значне місце в управлінні підприємствами у таких умовах належить стратегічному управлінню як ключовому фактору ритмічної роботи підприємства. У даному контексті стратегічне управління необхідно розуміти як систему вибору перспектив і скоординованих рішень, які здатні забезпечити динамічний розвиток підприємства. Чільне місце у системі стратегічного управління належить формуванню конкурентної стратегії. В умовах жорсткої внутрішньої та міжнародної конкуренції особливо актуальним $\epsilon$ питання визначення особливостей формування конкурентної стратегії для підприємств залізничного транспорту України. Недостатність нових теоретичних розробок спрямованих на вирішення проблем формування конкурентної стратегії для підприємств залізничного транспорту 3 урахуванням їх потенційних можливостей та ресурсного забезпечення зумовлюе необхідність та актуальність системного дослідження даної проблеми.

Аналіз досліджень та публікацій. На сьогодні теоретичні основи формування конкурентної стратегії та стратегічного управління на підприємстві $€$ досить розповсюдженими, їм присвячена ціла низка праць за авторством: О.С. Виханського [1], І.Ансоффа [2], Б.М. Шифріна [3], В.Л. Диканя, В.О. Зубенко, О.В. Маковоз, І.В.Токмакової, O.B. Шраменко [4], F.R. David [5], R.D. Stacey [6] та ін.

Підходи щодо розвитку залізничного транспорту України представлені в роботах: О.Б. Чернеги, В.С. Белозубенка, А.С. Расторгуєва [7], М. Макаренка, М. Цвєтова [8] та в існуючих програмних документах: Концепція розвитку транспортно-дорожнього комплексу України на середньостроковий період до 2020 року [9], Комплексна програма затвердження України як транзитної держави в 2002-2010 роках [10] та ін.

При безсумнівній наукової важливості цих досліджень ступінь розробленості питань формування конкурентної стратегії підприємств залізничного транспорту є недостатньою.

Mema cmammi. Метою статті $\epsilon$ визначення особливостей формування конкурентної стратегії для підприємств залізничного транспорту України.

Виклад основного матеріалу. Останнім часом істотно виросло значення стратегічного управління, що дозволяс будь-якій організації виживати в конкурентній боротьбі в довгостроковій перспективі. Особливо актуальним це стає для ПАТ «Українська залізниця», яке сьогодні змушене функціонувати в умовах жорсткої конкурентної боротьби (як на внутрішньому транспортному ринку, так і на зовнішньому) та в агресивному 
зовнішньому середовищі. Все це вимагає концентрувати увагу на внутрішньому стані справ на самому підприємстві, та виробляти довгострокову конкурентну стратегію, що дозволить ПАТ «Українська залізниця» встигати за змінами, що відбуваються в його оточенні.

Конкурентна стратегія являє собою основу конкурентної поведінки підприємства на ринку i описує схему забезпечення переваг над конкурентами, є центральним ланцюгом у стратегічному орієнтирі підприємства. Від ii правильного вибору залежать всі подальші виробничі, маркетингові, фінансові та інші дії підприємства [3]. Ця обставина визначає необхідність ретельного обгрунтування даної процедури. Однак, останнім часом у підприємницьких колах сформувались деякі стереотипи щодо того, як необхідно конкурувати на транспортному ринку, вони значною мірою заважають системно підійти до вирішення даної задачі.

Саме тому, 3 метою забезпечення ефективності діяльності підприємств залізничного транспорту України в сучасних умовах господарювання, виділимо ключові аспекти формування конкурентної стратегії.

Одним із вирішальних етапів $\epsilon$ аналіз зовнішнього середовища, оскільки розробку конкурентної стратегії необхідно починати 3 аналізу факторів, які знаходяться поза зоною постійного контролю керівництва та диктують умови щодо діяльності підприємств залізничного транспорту України.

Щодо підприємств залізничного транспорту, то слід зазначити, що останнім часом крім загального падіння обсягів перевезень, відбувся їх перерозподіл між видами транспорту, в першу чергу, на користь автомобільного транспорту, частка якого в перевезеннях цінних експортних та імпортних вантажів зросла.

Все це негативно позначилось на фінансовому стані залізничного транспорту України. Починаючи 3 2000p. борги Укрзалізниці почали поступово збільшуватись. В 2006р. вони перевищили доходи в 20 разів. 3 тих пір Укрзалізниця продовжила збільшувати борги. Загальна сума боргу Укрзалізниці на початок 2015 р. склала більш ніж 37 млрд. грн. Майже 22 млрд. грн припадає на внутрішній борг компаніï. На 01.05.2015p. виникла необхідність провести реструктуризацію 32 млрд. грн, що майже дорівнює всій сумі боргу.

Слід також зазначити, що сьогодні ПАТ «Українська залізниця» повинна бути готова до повного відкриття ринку транспортних послуг через кілька років, і керівництво підприємства повинно розуміти, що ці зміни будуть означати не тільки для самого підприємства, але й для економіки держави в цілому.

При виконанні SWOT-аналізу необхідно проаналізувати можливі зміни i 3'ясувати, яким буде ринок через п'ять або десять років. В першу чергу керівництво ПАТ «Українська залізниця» сьогодні повинно розуміти, що реформу, яка відбувається в галузі, слід сприйняти як шанс використати можливості відкритого ринку. Саме тому заплановані стратегічні дії повинні бути більш гнучкими i, по можливості, мати міжнародне спрямування. Адже проведений аналіз показав, що "Укрзалізниця" має економічні переваги порівняно 3 DB Schenker, яка працює 3 Німеччини, і тому має більш високі витрати на персонал, ніж "Укрзалізниця". 3 іншого боку, DB Schenker перевозить набагато менший обсяг вантажів, ніж "Укрзалізниця", але іiі дохід від вантажів, як і раніше значно вище (близько 5 млрд євро). Якщо говорити про DB Schenker або, наприклад, про ОВВ, вони починали як залізничні оператори, в даний час вони $\epsilon$, швидше, логістичними компаніями, які використовують свій потенціал по логістичному ланцюгу. Їх бізнес змінився від перевезення важких вантажів на все більш i більш інтермодальні контейнерні перевезення та інші транспортні послуги.

Також при виробленні ефективної конкурентної стратегії підприємств залізничного транспорту України необхідно звернути увагу на ринкові тенденції та перспективи. Очікується, що майбутній ріст вантажних перевезень (на 40\% до 2025 року) буде відбуватися по Свропейсько-Азійського коридору. ПАТ «Українська залізниця» повинна спробувати отримати значну частку цього зростання, використовуючи центральну позицію України між Свропою та Азією.

Крім того, нещодавно DHL підписала угоду із залізницями Казахстану для забезпечення залізничного сполучення i торгівлі між Китаєм і Європою. Таким чином, ці гравці $\epsilon$ майбутніми клієнтами ПАТ «Українська залізниця», і керівництво 
підприємства повинно слідувати цій тенденції ринку, щоб отримати у майбутньому велику частку в бізнесі.

Після дослідження головних конкурентів слід зазначити, що в Свропі, після відкриття ринку вантажоперевезень, відбулося багато змін, із-за яких два великих гравці - DB Schenker SNCF Geodis - втратили конкурентні позиції. Привабливі вантажні лінії піддаються атакам 3 боку інвесторів і нішевих гравців. Тим не менш, залізничні оператори розширили їх доступ на ринок. Ось чому вони почали переростати в логістичні конгломерати - щоб отримати якомога більшу частку у вантажному бізнесі.

Наступним вирішальним етапом у формуванні ефективної конкурентної стратегії для підприємств залізничного транспорту є той факт, що стратегія, яка використовується компанією, швидко перетворюється в типову, тобто вже не дає конкурентних переваг, хоча і породжує зміни в загальному контексті конкуренції. Тому слід врахувати, що вже після формування конкурентної стратегії слід вирішити три взаємопов'язані завдання: 1 . Управління стратегією на ринку: розробка, реалізація та уточнення стратегій, що забезпечують перемогу на ринку. 2. Управління організацією: внутрішні зміни організації, визначають іiі дії на ринку, і спрямованість цих дій. Це дозволяє ій адекватно реагувати на зміни навколишнього середовища, адаптуватися до них і використовувати в своїх цілях. 3. Реалізація стратегічного менеджменту: взаємодія між стратегією (тим, що організація робить на ринку) і організаційними процесами (тим, що відбувається в самій організації).

Висновок. В умовах жорсткої конкуренції та глобалізації формування шляхів забезпечення конкурентоспроможності підприємств залізничного транспорту та відповідно ефективності всієї галузі є життєво важливим завданням, адже залізничний транспорт України спроможний стати ключовою ланкою в процесі забезпечення сталого розвитку всієї економіки країни. Саме тому, формування якісної конкурентної стратегії підприємств залізничного транспорту $€$ запорукою успіху вітчизняної економіки.

\section{СПИСОК ЛІТЕРАТУРИ}

1. Виханский О. С. Стратегическое управление [Текст] : учебник. / О. С. Виханский. - 2-е изд., перераб. и доп. - М. : Гардарики, 2005.- 169 с.

2. Ансофф И. Стратегическое управление [Текст] / И. Ансофф ; пер. с англ. М.: Экономика, 1989. - 358 с.

3. Шифрин М.Б. Стратегический менеджмент [Текст]: учеб. пособие / М.Б. Шифрин. - ЧПб: Питер, 2009. - 240 с.

4. Дикань В.Л. Стратегічне управління [Текст]: навч.посіб./ В.Л.Дикань, В.О.Зубенко, О.В. Маковоз, І.В. Токмакова, О.В.Шраменко. К: «Центр учбової літератури», 2013. - 272с.

5. David F.R. Strategic Management: Concepts and Cases / F.R. David //13th edition. Prentice Hall, 2011. - 694 p.

6. Stacey R.D. Strategic management and organisational dynamics: The challenge of complexity to ways of thinking about organisations / R.D. Stacey. - Prentice Hall - 2011. - 560 p.

5 Чернега О.Б. Основные структурные особенности реализации транспортнотранзитного потенциала Украины [Текст] /О.Б. Чернега, В.С. Белозубенко, А.С. Расторгуев// Вісник Хмельницького національного університету. Сер.: Економ. науки. Т. 3. Хмельницький: ХНУ, 2008. - №3. - $\quad$ С. 101106.

6 Макаренко М. Транспортний сектор економіки України: тенденції та проблеми розвитку /М. Макаренко, М. Цвєтов [Текст] // Економіст. - 2007. - №6. - С. 24-27.

7. Концепція розвитку транспортнодорожнього комплексу України на середньостроковий період та до 2020 року [Електронний ресурс] //Офіційний сайт Міністерства транспорту і зв'язку України // Режим доступу: www.mtu.ua.

8. Комплексна програма утвердження України як транзитної держави у 2002-2010 роках [Електронний ресурс] // Офіційний сайт Міністерства транспорту і зв'язку України // Режим доступу: www.mtu.ua.

Рецензент д.е.н., професор УкрДУЗТ Чебанова Н.В. Експерт редакційної колеаії к.е.н., дочент УкрДУЗТ Зубенко В.О.

Вісник економіки транспорту і промисловості № 51, 2015 